\title{
Perawatan endodontik konvensional pada gigi molar pertama kanan rahang bawah dengan kista radikuler Conventional endodontic treatment in lower right first molar with radicular cyst
}

\author{
${ }^{1}$ Badi Soerachman, ${ }^{2}$ Moch. Richata Fadil, ${ }^{2}$ Endang Sukartini, ${ }^{2}$ Milly Armilia \\ ${ }^{1}$ Program Studi Kedokteran Gigi, Fakultas Kedokteran, Universitas Ahmad Jani \\ ${ }^{2}$ Bagian Konservasi Gigi, Fakultas Kedokteran Gigi, Universitas Padjajaran \\ Bandung, Indonesia
}

\begin{abstract}
Abnormalities of the teeth that have had periapical endodontic treatment generally due to recurrent infections of root canal. Infection of the root canal is caused by leakage due to poor quality of coronal restoration and iatrogenic factors. Root canal treatment of the tooth with periapical cyst generally do conventionally. Medication materials used for healing of periapical lesions is calcium hydroxide, since it has properties not irritating, alkaline $\mathrm{pH}$ and antibacterial capabilities, so it is a biological stimulator for the formation of hard tissue in the area of damage and is expected to accelerate the healing process. It was reported the case of a 23-year-old student came to the Dental clinic of Conservation Specialist RSGM Sekeloa with complaints lower right back teeth has restored with amalgam, no pain, but less comfortable when chewing. The results obtained after treatment with calcium hydroxide and medikamen gutta percha filling with resin-based root canal cement. Approximately 4 months later, the periapical radiolucent area had thinned. So it was concluded that conventional endodontic treatment proved to heal periapical lesions including cysts, as long as the treatment is taken adequately.
\end{abstract}

Key words: periapical lesions, cysts, conventional endodontic treatment, calcium hydroxide

\begin{abstract}
ABSTRAK
Kelainan periapikal pada gigi yang telah dilakukakan perawatan endodontik umumnya disebabkan karena adanya infeksi saluran akar yang berulang. Infeksi pada saluran akar disebabkan oleh kebocoran koronal akibat restorasi yang tidak baik dan faktor iatrogenik. Perawatan saluran akar pada kelainan periapikal dengan kasus kista pada umumnya dapat dilakukan secara konvensional. Bahan medikamen yang digunakan untuk penyembuhan lesi periapikal adalah kalsium hidroksida, karena memiliki sifat tidak iritatif, $\mathrm{pH}$ alkali dan kemampuan antibakteri, sehingga merupakan stimulator biologis untuk pembentukan jaringan keras di daerah kerusakan dan diharapkan akan mempercepat proses penyembuhan. Dilaporkan kasus seorang mahasiswa berusia 23 tahun datang ke klinik Spesialis Konservasi Gigi RSGM Sekeloa dengan keluhan gigi belakang kanan bawah telah ditambal amalgam, tidak sakit, namun gigi kurang nyaman jika dipakai mengunyah. Hasil yang didapat setelah melakukan perawatan dengan medikamen kalsium hidroksida dan pengisian dengan gutta percha dan semen saluran akar berbasis resin. Kurang lebih 4 bulan kemudian terlihat gambaran radiolusen di daerah periapikal telah menipis. Dari hal tersebut, dapat disimpulkan bahwa perawatan endodontik konvensional terbukti dapat menyembuhkan lesi periapikal termasuk kista, selama perawatan dilakukan dengan adekuat.
\end{abstract}

Kata kunci: lesi periapikal, kista, perawatan endodontik konvensional, kalsium hidroksida

Koresponden: Badi Soerachman, Program Studi Kedokteran Gigi, Fakultas Kedokteran Universitas Ahmad Jani, Jl. Terusan Jenderal Sudirman, Cimahi Jawa Barat, Indonesia. E-mail: badi_soerachman@yahoo.com 